\title{
Structure of cag pathogenicity island in Japanese Helicobacter pylori isolates
}

\author{
S Maeda, H Yoshida, T Ikenoue, K Ogura, F Kanai, N Kato, Y Shiratori, M Omata
}

\begin{abstract}
Background-cag pathogenicity island (PAI) is reported to be a major virulence factor of Helicobacter pylori.

Aim-To characterise cagA and the cag PAI in Japanese $H$ pylori strains. Methods-H pylori isolates from Japanese patients were evaluated for CagA by immunoblot, for $\operatorname{cag} A$ transcription by northern blot, and for $\operatorname{cag} A$ and 13 other cag PAI genes by Southern blot. $\operatorname{cag} A$ negative strains from Western countries were also studied. Induction of interleukin-8 secretion from gastric epithelial cells was also investigated.
\end{abstract}

Results-All Japanese strains retained $\operatorname{cag} A$. Fifty nine of 63 (94\%) strains had all the cag PAI genes. In the remaining four, cag PAI was partially deleted, lacking $\operatorname{cag} A$ transcripts and not producing $\operatorname{CagA}$ protein. Details of the PAI of these strains were checked; three lacked $\operatorname{cag} B$ to $\operatorname{cag} Q$ (cagI) and continuously cagS to cag13 (cagII), and the remaining one lacked $\operatorname{cag} B$ to $\operatorname{cag} 8$. Western $\operatorname{cag} A$ negative strains completely lacked cag PAI including $\operatorname{cag} A$. Nucleotide sequence analysis in one strain in which the cag PAI was partially deleted showed that the partial deletion contained $25 \mathrm{~kb}$ of cag PAI and the $\operatorname{cag} A$ promoter. Interleukin-8 induction was lower with the cag PAI partial deletion strains than with the intact ones. All Japanese cag PAI deleted strains were derived from patients with non-ulcer dyspepsia, whereas 41 of $59(70 \%)$ CagAproducing strains were from patients with peptic ulcers or gastric cancer $(p<0.05)$. Conclusions-Most Japanese $H$ pylori strains had the intact cag PAI. However, some lacked most of the cag PAI in spite of the presence of $\operatorname{cag} A$. Thus the presence of the $\operatorname{cag} A$ gene is not an invariable marker of cag PAI related virulence in Japanese strains.

(Gut 1999;44:336-341)

Internal Medicine,

Faculty of Medicine,

University of Tokyo,

7-3-1 Hongo,

Bunkyo-ku, Tokyo 113, Japan

S Maeda

H Yoshida

T Ikenoue

K Ogura

F Kanai

N Kato

Y Shiratori

M Omata

Correspondence to: Dr S Maeda.

Accepted for publication 23 September 1998

ulcers and gastric cancer occur only in a subset of infected patients. ${ }^{1-6}$ Although the pathogenesis of $H$ pylori infection is not well understood, several factors have been proposed as possible virulence determinants.

The CagA surface protein is one of the most investigated putative virulence factors, en- coded by the $\operatorname{cag} A$ gene. ${ }^{78}$ The gene is found in about $50-70 \%$ of $H$ pylori isolates in Western countries, and the production of CagA protein is reported to be associated with advanced gastroduodenal diseases. ${ }^{9-16}$ CagA positive $H$ pylori strains are known to induce interleukin-8 (IL-8) secretion from gastric epithelial cells. ${ }^{17-19}$ However, recent studies have indicated that it is not CagA itself but the products of other genes in the cag pathogenicity island (PAI) that are responsible for IL-8 induction..$^{20-23}$ The cag PAI is an approximately $40 \mathrm{~kb}$ region in the $H$ pylori genome, possibly of extraneous origin. ${ }^{2021}{ }_{24} \mathrm{It}$ is divided into two parts: the upstream cagII region containing at least 14 genes, and the downstream cagI region containing 16 genes. The cag $A$ gene is located in the most downstream portion of cagI. In some strains, the two parts of the cag PAI are reported to be interposed by a segment called insertion sequence 605 (IS605). ${ }^{21}$

Previous reports indicated that most $\operatorname{cag} A$ positive strains, most of which are capable of producing CagA protein, ${ }^{78}$ retain all the other genes of the cag PAI, whereas most $\operatorname{cag} A$ negative strains completely lack the cag PAI. ${ }^{21}$ This implies that the presence of the $\operatorname{cag} A$ gene may be used as a marker of enhanced virulence associated with the cag PAI. However, Censini et $a l^{1}$ reported partial deletion of the cag PAI. Thus the status of the $\operatorname{cag} A$ gene and the other cag PAI genes should be individually investigated.

By using recombinant CagA and antibodies raised against it, we have previously shown that the prevalence of CagA-non-producing $H$ pylori strains is relatively low in Japan (about $10 \%) .{ }^{25}{ }^{26}$ However, these strains had not been characterised, and we conducted the present study to elucidate the relation between $\operatorname{cag} A$ and the other cag PAI genes in Japanese isolates.

\section{Materials and methods}

PATIENTS

$H$ pylori strains were isolated from gastric biopsy specimens of $63 H$ pylori infected patients who had undergone endoscopy in Tokyo University Hospital. The patient population consisted of 40 men and 23 women with a mean age of 52.5 (range 22-78). The endoscopic findings were as follows: gastric ulcer (13); duodenal ulcer (12); non-ulcer dyspepsia (22); gastric cancer (16).
Abbreviations used in this paper: IL, interleukin; IS605, insertion sequence 605; PAI, pathogenicity island; SDS-PAGE, sodium dodecyl

sulphate-polyacrylamide gel electrophoresis, SSC, standard saline citrate. 
Table 1 Oligonucleotide primers used in this study

\begin{tabular}{|c|c|c|}
\hline Primer designation & Primer sequence & Location (reference) \\
\hline $\operatorname{cag} A-\mathrm{F}$ & 5'-AGCTGCAGCATGACTAACGAAAACTATTGACCAAC-3' & $(1)$ \\
\hline $\operatorname{cag} A-\mathrm{R}$ & 5'-AGCTGCAGCTTAAGATTTTTGGAAACCACCTTTT-3' & (1) \\
\hline $\operatorname{cag} B-\mathrm{F}$ & 5'-ATGGAAAACAAATCAATAGG-3' & $\left(18495-18514^{\star}\right)$ \\
\hline $\operatorname{cagB}-\mathrm{R}$ & 5'-CTACTTGTCCCAACCATTTT-3' & $\left(18287-18268^{\star}\right)$ \\
\hline $\operatorname{cag} C-\mathrm{F}$ & 5'-ATGAAATTTTTTACAAGAAT-3' & $\left(18142-18123^{\star}\right)$ \\
\hline $\operatorname{cag} C-\mathrm{R}$ & 5'-TTAGCTAGCTCCTCCACCCT-3' & $\left(17795-17814^{\star}\right)$ \\
\hline cagE-F & 5'-TCTATAAAGAGAGGGGTGTT-3' & $\left(17170-17151^{\star}\right)$ \\
\hline $\operatorname{cag} E-\mathrm{R}$ & 5'-GGCTAATCTTTGGTAATCAG-3' & $\left(14451-14469^{\star}\right)$ \\
\hline cagM-F & 5'-ATGCTTGCAAAAATTGTTTT-3' & $\left(7772-7791^{\star}\right)$ \\
\hline cagM-R & 5'-CTATTCAAAGGGATTATTCT-3' & $\left(8902-8883^{\star}\right)$ \\
\hline $\operatorname{cagN}-\mathrm{F}$ & 5'-GTCGCTCTTTATTCTTTAGT-3' & $\left(9837-9818^{\star}\right)$ \\
\hline $\operatorname{cag} N-\mathrm{R}$ & 5'-CTATTTTTTTCCATGAGCGA-3' & $\left(8947-8966^{\star}\right)$ \\
\hline $\operatorname{cag} Q-\mathrm{F}$ & 5'-CGTGTTTTAGTAGGAAGCAT-3' & $\left(6570-6551^{\star}\right)$ \\
\hline $\operatorname{cag} Q-\mathrm{R}$ & 5'-CTACAGTCTTACTTGAGAGA-3' & $\left(6190-6209^{\star}\right)$ \\
\hline $\operatorname{cag} T-\mathrm{F}$ & 5'-ATGAAAGTGAGAGCAAGTGT-3' & $\left(344-363^{\star}\right)$ \\
\hline $\operatorname{cag} T-\mathrm{R}$ & 5'-TCACTTACCACTGAGCAAAC-3' & $\left(1186-1167^{\star}\right)$ \\
\hline cag15-F & 5'-TTATTTATCTCTGACAAGAG-3' & $\left(17463-17444^{\star \star}\right)$ \\
\hline cag15-R & 5'-ATGGGGCAGGCATTTTTTAA-3' & $\left(17084-17105^{\star \star}\right)$ \\
\hline cag13-F & 5'-GCTAGAGAAAAGGCTGTTGC-3' & $\left(12771-12752^{\star \star}\right)$ \\
\hline cag13-R & 5'-TGGCGTTAATAGTGGCAATA-3' & $\left(12369-12388^{\star \star}\right)$ \\
\hline cag12-F & 5'-ТTATTCCAAATTTAATTTTA-3' & $\left(11542-11523^{\star \star}\right)$ \\
\hline cag12-R & 5'-ATGGAACTCGGTTTCAATGA-3' & $\left(11103-11122^{\star \star}\right)$ \\
\hline cag10-F & 5'-ATGGAAGACTTTTTGTATAA-3' & $\left(9498-9479^{\star \star}\right)$ \\
\hline cag10-R & 5'-TCACAGTTCGCTTGAACCCA-3' & $\left(7271-7290^{\star \star}\right)$ \\
\hline cag6-7-F & 5'-ATGGCAACATGGAGATGGTT-3' & $\left(4289-4308^{\star \star}\right)$ \\
\hline cag6-7-R & 5'-TTAGTTTCCTTTTTTTCAG-3' & $\left(5174-5155^{\star \star}\right)$ \\
\hline cagLEC-F & 5'-ACATTTTGGCTAAATAAACGCTG-3' & $\left(3920-3942^{\star \star}\right)$ \\
\hline $\operatorname{cag} L E C-\mathrm{R}$ & 5'-ATCTTTAGTCTCTTTAGC-3' & $\left(4732-4715^{\star \star}\right)$ \\
\hline IS-F & 5'-CGCCTTGATCGTTTCAGGATTAGC-3' & $\left(4229-4253^{\star}\right)$ \\
\hline IS-R & 5'-CAACCAACCGAAGCAAGCATAATC-3' & $\left(2596-2719^{\star}\right)$ \\
\hline
\end{tabular}

(1) Reference 25

${ }^{\star}$ GenBank accession number U60176.

${ }^{\star \star}$ GenBank accession number AC000108.

\section{H PYLORI CULTURE}

Biopsy specimens were cultured on Columbia agar with $5 \%(\mathrm{v} / \mathrm{v})$ horse blood and Dent antibiotic supplement (Oxoid, Basingstoke, Hants, UK) at $37^{\circ} \mathrm{C}$ for five days under microaerobic conditions (Campy-Pak Systems; BBL, Cockeysville, Maryland, USA). The organisms were identified as $H$ pylori by Gram stain morphology, colony morphology, and positive urease, catalase, and oxidase activities. The isolates were kept at $-80^{\circ} \mathrm{C}$ in Brucella broth with $5 \%(\mathrm{v} / \mathrm{v})$ fetal bovine serum (FBS) containing $16 \%(\mathrm{v} / \mathrm{v})$ glycerol.

DETECTION OF CAgA PROTEINS IN H PYLORI ISOLATES

Western blot analysis was performed to detect CagA proteins produced by $H$ pylori strains as previously described. ${ }^{25}$ CagA protein was investigated using $H$ pylori whole cell lysates. The whole cell lysates were washed twice in normal saline, centrifuged, and boiled at $100^{\circ} \mathrm{C}$ for five minutes in Laemmli sample buffer ${ }^{27}$ before use. The whole cell lysates were separated by sodium dodecyl sulphate-polyacrylamide gel electrophoresis (SDS-PAGE) (10\% gel) and transferred to a nitrocellulose membrane (Schleicher \& Schuell, Dassel Germany). The filter was blocked with buffer containing $5 \% \quad(\mathrm{v} / \mathrm{v})$ skimmed milk in $25 \mathrm{mM}$ Tris/ $\mathrm{HCl}, \mathrm{pH} 7.4$, containing $150 \mathrm{mM} \mathrm{NaCl}$ and $5 \mathrm{mM} \mathrm{KCl}$. The membrane was incubated with a 1:100 dilution of rabbit antiserum against the recombinant CagA. After being washed, the membrane was incubated with ${ }^{125} \mathrm{I}$-labelled goat anti-rabbit IgG, and then exposed to $x$ ray film.

PREPARATION OF GENOMIC DNA

$H$ pylori bacterial cells, suspended in $10 \mathrm{mM}$ Tris/ $\mathrm{HCl}, \mathrm{pH}$ 7.5, containing $1 \mathrm{mM}$ EDTA,

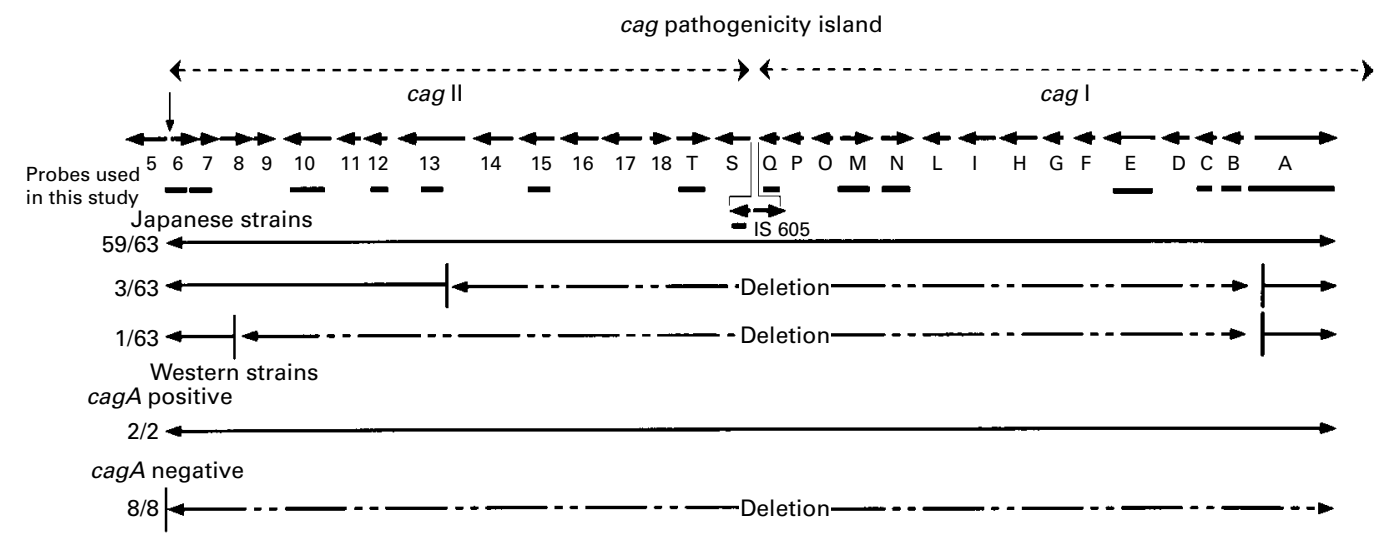

Figure 1 Map of the cag pathogenicity island. The names of the genes are from GenBank accession number AC000108 and U60176. Cross bars indicate probes used in this study. Fifty nine of 63 strains isolated in fapan all had cagI and cagII. Large deletions were revealed in the remaining four. cagA negative strains isolated in Western countries lacked whole cagI and cagII. 
were treated with $0.3 \%$ SDS and $0.6 \mathrm{mg} / \mathrm{ml}$ proteinase $\mathrm{K}$ at $60^{\circ} \mathrm{C}$ overnight. DNA was extracted with phenol, phenol/chloroform and chloroform, precipitated with ethanol, and suspended in TE. The DNA was stored at $-20^{\circ} \mathrm{C}$ until use.

CLONING OF THE GENES OF THE $C A G$ REGION

DNA was extracted from $H$ pylori ATCC 43579 cells. Oligonucleotide primers were designed to amplify the genes of the cag region; $\operatorname{cag} A, \operatorname{cag} B, \operatorname{cag} C, \operatorname{cagE}$ (picB), cagM, cagN, cag $Q$, cag $T$, cag15, cag13, cag12, cag10, cag6-7, IS605, and the left end of the cag region (LEC) which contained both inside and outside genes of the cag PAI according to the nucleotide sequences of the cag region previously reported (GenBank accession numbers AC000108 and U60176) (table 1, fig 1). PCR cycling conditions were 30 cycles of $94^{\circ} \mathrm{C}$ for 30 seconds, $50^{\circ} \mathrm{C}$ for 30 seconds, and $72^{\circ} \mathrm{C}$ for one to two minutes. The PCR products were cloned into pCRII using the original TA cloning kit (Invitrogen, San Diego, California, USA). The nucleotide sequence of the insert was determined by the dideoxy chain termination procedure. ${ }^{28}$ Cloned plasmids were digested with EcoRI and BstXI, which were able to digest the full length of the PCR products, and the digests electrophoresed on $1 \%$ agarose gel. The appropriate fragments were then excised from the gels and the DNA extracted with the gene clean kit to be used as probes (Bio 101, La Jolla, California, USA).

SOUTHERN BLOT ANALYSIS

For each sample, $5 \mu \mathrm{g}$ of the genomic DNA was digested with HindIII for 12 hours at $37^{\circ} \mathrm{C}$, electrophoresed on $1 \%$ agarose gel, and transferred to a nylon membrane (Amersham International, Bucks, UK) as described by Sambrook et $a .^{29}$ The DNA samples were hybridised to previously prepared DNA probes, which were digested from cloned plasmids and labelled with $\left[{ }^{32} \mathrm{P}\right] \mathrm{dCTP}$ with the Ready To Go DNA labelling kit (Pharmacia Biotech, Uppsala, Sweden). The membrane was prehybridised with ExpressHyb solution (Clontech, Palo Alto, California, USA) at $60^{\circ} \mathrm{C}$ for one hour, and hybridisation was carried out at $60^{\circ} \mathrm{C}$ for two hours. The membrane was washed four times with $2 \times$ standard saline citrate (SSC) $/ 0.05 \%$ SDS for 10 minutes at room temperature, twice with $0.1 \times \mathrm{SSC} / 0.1 \% \mathrm{SDS}$ for 20 minutes at $50^{\circ} \mathrm{C}$, and then autoradiography was performed using a BAS2000 image analyser (Fuji Photo Film Co, Ltd, Tokyo, Japan).

RNA EXTRACTION AND NORTHERN BLOT ANALYSIS OF cagA TRANSCRIPTS

$H$ pylori bacterial cells were washed with normal saline and suspended in TE. Total RNA was extracted using Rneasy Total RNA kit (Qiagen, Chatsworth, California, USA). For each sample, $10 \mu \mathrm{g}$ total RNA was electrophoresed on formamide-agarose gel and transferred to a nylon membrane (Amersham International). The hybridisation was performed using the cag $A$ gene as described above, except that the membrane was kept at $68^{\circ} \mathrm{C}$ instead of $60^{\circ} \mathrm{C}$, and washed four times with $2 \times$ SSC $/ 0.05 \%$ SDS for 10 minutes at room temperature, twice with $0.1 \times \mathrm{SSC} / 0.1 \%$ SDS for 20 minutes at $50^{\circ} \mathrm{C}$, and then exposed to $x$ ray film.

SEQUENCE ANALYSIS OF caga NEGATIVE STRAIN The nucleotide sequence of $\operatorname{cag} A$ and the upstream transcript of $\operatorname{cag} A$ genes were analysed in one of the cag $A$ negative strains, T-94. Preliminary analysis using 15 primers designed inside the $\operatorname{cag} A$ gene revealed that nucleotides from position 910 to the terminal codon were retained. Subsequently, a primer named $\operatorname{cag} A$ 20R (5'-TTGGTCTTTATAACCAACGG-3' corresponding to $\operatorname{cag} A$ position $1020-1001$ ) was designed. PCR was performed using $\operatorname{cag} A$ 20R and 10 previously described random primers. ${ }^{30}$ The amplicons were cloned into the pCRII vector using the original TA cloning kit (Invitrogen). The cloned samples were screened by colony hybridisation. The Escherichia coli colonies were transferred to a nylon membrane (Amersham International). The hybridisation was performed using the full length of the $\operatorname{cag} A$ gene as probe. Hybridysation and washing were performed as for the Southern blot described above. Plasmid DNA was extracted from positive colonies and the nucleotide sequence of the insert determined by the dideoxy chain termination procedure. ${ }^{28}$

STIMULATION OF IL-8 SECRETION IN GASTRIC EPITHELIAL CELL LINES

Experiments were performed as previously described. ${ }^{17}{ }^{18} \mathrm{H}$ pylori strains were harvested in Brucella broth containing 7.5\% FBS for 24 hours at $37^{\circ} \mathrm{C}$. After centrifugation, they were resuspended at $8 \times 10^{7} \mathrm{cells} / \mathrm{ml}$ in RPMI 1640 containing $10 \% \mathrm{FBS}$ and used immediately.

MKN-28 cells were routinely maintained in RPMI 1640 supplemented with 10\% FBS. Confluent monolayers of MKN-28 cells in 24 well plates were co-cultured with $H$ pylori strains for 16 hours in quadruplicate. Supernatants were then aspirated and stored at $-70^{\circ} \mathrm{C}$ until assayed for IL-8 by enzyme immunoassay (PerSeptive Diagnostics, Framingham, Massachusetts, USA). Concentrations of IL-8 were determined from a standard curve of recombinant IL-8. Bacterial induced IL-8 secretion was expressed as $\mathrm{ng} / \mathrm{ml}$ after subtraction of background unstimulated control culture values.

STATISTICAL ANALYSIS

Differences in categorised data were analysed with Fisher's exact probability test, and differences in mean values by analysis of variance. $\mathrm{p}<0.05$ was considered significant.

\section{Results}

DETECTION OF CagA PROTEIN

CagA protein was detected by western blot analysis as previously described. Overall, 57 of $63(90 \%)$ strains were positive for CagA protein. The prevalence of CagA protein positive strains was $12 / 13$ for patients with gastric 
ulcer, 11/12 for those with duodenal ulcer, $18 / 22$ for patients with non-ulcer dyspepsia, and 16/16 for gastric cancer patients.

SOUTHERN BLOT ANALYSIS OF cagA GENE

Southern blot analysis of chromosomal DNA derived from $63 \mathrm{H}$ pylori strains cleaved with HindIII revealed that all $63(100 \%)$ strains isolated in Japan were positive for the $\operatorname{cag} A$ gene. Six strains that were negative for CagA protein, as determined by western blot analysis, also had the $\operatorname{cag} A$ gene. Some restriction fragment length polymorphism patterns were observed, but no relation was found between gastroduodenal disease and these patterns. We also analysed two $\operatorname{cag} A$ positive and eight $\operatorname{cag} A$ negative strains isolated in the Western countries as controls. Negative strains did not contain $\operatorname{cag} A$ gene, as expected.

NORTHERN BLOT ANALYSIS OF cagA TRANSCRIPTS To determine whether CagA protein expression is inhibited at the transcriptional level, we analysed 17 CagA protein positive strains and six CagA protein negative strains isolated in Japan. All 17 positive strains had cagA transcripts. In the negative strains, two of six had cag $A$ transcripts, but the remaining four did not. ATCC 43526 and 43579 were used as positive controls, and Tx30a was used as a negative control (fig 2).

SOUTHERN BLOT ANALYSIS OF cagI

The $H$ pylori isolates were analysed for the $\operatorname{cag} B, \operatorname{cag} C, \operatorname{cagE}(p i c B), \operatorname{cag} M, \operatorname{cagN}$, and $\operatorname{cag} Q$ genes of the cagI region. Overall, 59/63 (94\%) strains had all the cagI genes, but the remaining four $(6 \%)$ lacked all six cagI genes in spite of the presence of the cag $A$ gene. Surprisingly,
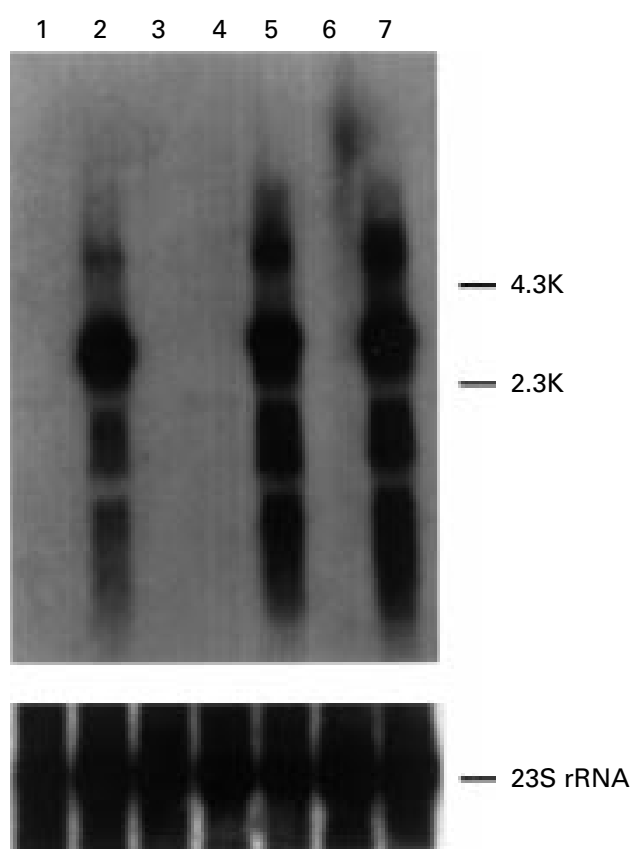

Figure 2 Northern blot analysis of cagA transcripts from seven strains. cagA transcripts were present in T-57 (lane 2), T-1 (lane 5), and ATCC 43526 (lane 7), and absent from T-94 (lane 1), T-85, T-25 (lanes 3 and 4), and Tx30a (lane 6). The membrane was also hybridised to $23 S$ $r R N A$ to monitor the amount of RNA loaded.
Table 2 Relation between IS605 and cag region of $H$ pylori

\begin{tabular}{lccc}
\hline & IS605 + & IS605 - & Total \\
\hline All PAI + & 18 & 41 & 59 \\
Partial PAI + & 2 & 2 & 4 \\
All PAI - & 3 & 5 & 8 \\
Total & 23 & 48 & 71 \\
\hline
\end{tabular}

PAI, pathogenicity island.

*The strains lacking all PAI were isolated in Western countries. These strains were kindly provided by Dr John Atherton (Nottingham, UK).

four strains that lacked $\operatorname{cagI} \operatorname{did}$ not have $\operatorname{cag} A$ transcripts and CagA protein. In the strains derived from patients with non-ulcer dyspepsia, 4/22 (18\%) strains did not have cagI, whereas all 41 strains from patients with peptic ulcer and gastric cancer had cagI. This difference was statistically significant $(p<0.05$; Fisher's exact probability test). ATCC 43526 and 43579 had all the genes of cagI, and eight CagA negative strains including Tx30a lacked cagI.

\section{SOUTHERN BLOT ANALYSIS OF CagII}

We analysed cagT, cag15, cag13, cag12, cag10, and cag6-7 of cagII, and LEC. All isolates with all cagI genes (59 strains) were positive for all six cagII genes. All clinical isolates (63 strains) hybridised with cag6-7 irrespective of the presence of cagI. In the analysis of cagT and cag15, strains that had cagI all had these genes, but four strains without cagI did not have cagT and cag15 genes. In the analysis of cag13, cag12, and cag10 genes, strains that had cagI all had cag13, cag12, and cag10 genes, in four strains without cagI, three strains had cag13, cag12, and cag10 genes, and one strain did not have these genes. ATCC 43526 and 43579 had all the cagII genes and eight CagA negative Western strains including Tx30a lacked all the cagII genes (fig 1). All 73 strains used in this study hybridised with the $L E C$.

SOUTHERN BLOT ANALYSIS OF IS 605

Overall, 20/63 (31\%) Japanese strains had IS605. The existence of IS605 was not related to the existence of cag PAI nor to gastroduodenal status in the host. We also investigated IS605 in eight PAI negative strains isolated in Western countries, and three of the eight (38\%) were positive (table 2).

JUNCTIONAL SEQUENCES OF THE cag PAI DELETED REGION

Sequence analysis of the T-94 strain revealed that the $\operatorname{cag} A$ gene was truncated at position 500, and the cag13 sequence was found directly upstream. About $25 \mathrm{~kb}$ of cag PAI including the $\operatorname{cag} A$ promoter region was deleted, and no insertional sequences were found in the junctional region (fig 3).

\section{H PYLORI STIMULATION OF IL-8 SECRETION IN} GASTRIC EPITHELIAL CELL LINES

We analysed IL-8 stimulation by 16 strains: 10 clinical isolates and ATCC 43579, which were CagA protein and PAI positive; four clinical isolates (T-25, T-68, T-85, T-94), which were characterised as CagA protein negative with 

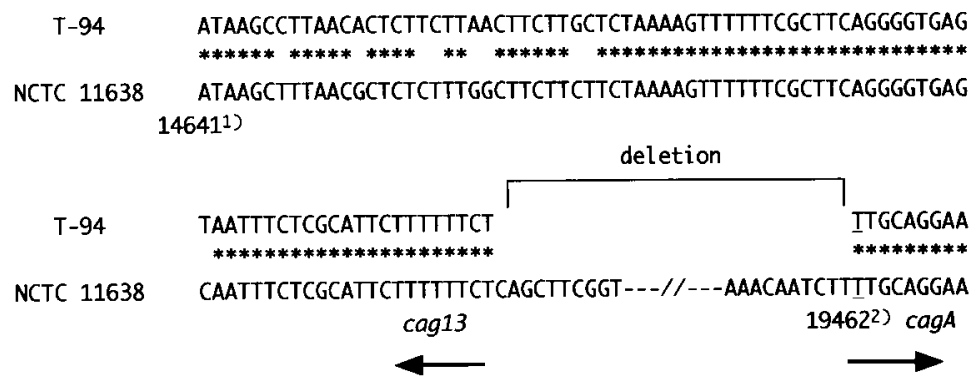

T-94 TTATCATAGGGAACCAAATCCGATCGGATGAAAAATTCATGGGCGTGTTTGATGAATCTT NCTC 11638 TCATTATAGGGAATCAAATCCGAACGGATCAAAAGTTCATGGGCGTGTTTGATGAGTCCT

Figure 3 Functional sequences of T-94, which has cag PAI deleted. cagII was present down to position 14723 (GenBank accession number AC000108) in the middle of cag13. The cagA gene was present up to position 19462 (GenBank accession number U60176). This position is equal to position 500 of the cag $A$ gene. An approximately $25 \mathrm{~kb}$ segment of cag PAI was deleted. 1) indicates the position of GenBank accession number AC000108. 2) indicates the cagA position of GenBank accession number U60176. Asterisks denote identity.

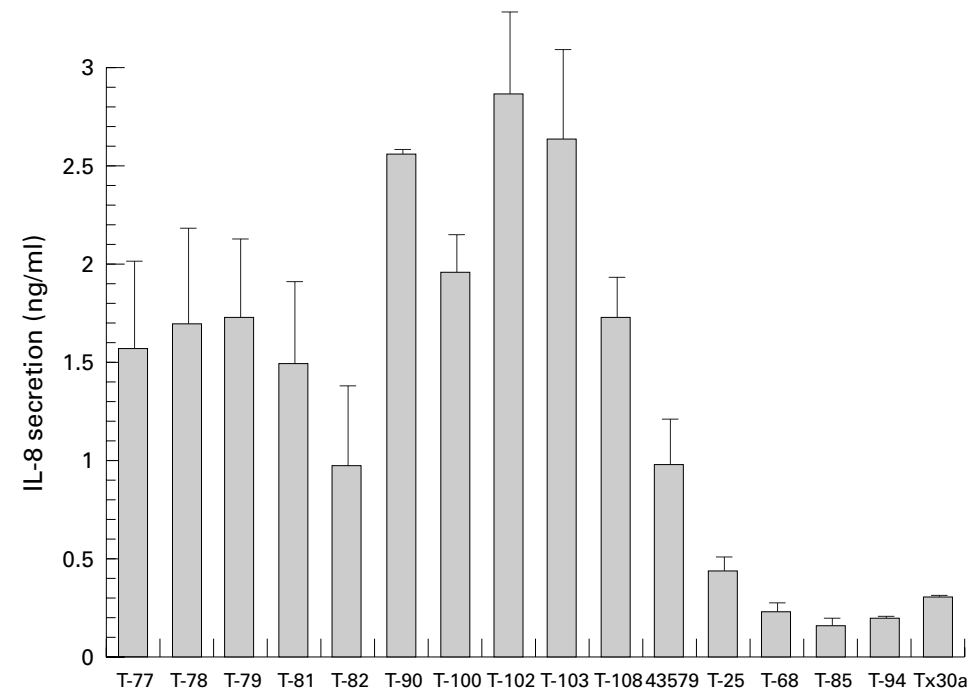

Figure 4 Secretion of interleukin-8 (IL-8) from MKN-28 cells over the 16 hours after stimulation. T-77, T-78, T-79, T-81, T-82, T-90, T-100, T-102, T-103, T-108 strains were clinical isolates with an intact cag pathogenicity island (PAI). 43579 indicates ATCC 43579. Tx30a is a strain with cag PAI completely deleted. In T-25, T-68, T-85, and T-94, cag PAI was partially deleted. Results are expressed as the mean and SD from four to six experiments.

PAI deleted; and the cag PAI negative Tx30a. As shown in fig 4, IL-8 secretion induced by the PAI deleted strains and Tx30a was significantly lower than that induced by ATCC 43579 and the other cag PAI positive isolates $(\mathrm{p}<0.05$; analysis of variance). These results indicate that intact cag PAI is necessary for the stimulation of IL-8 secretion, and the $\operatorname{cag} A$ gene is not an appropriate marker of IL-8 secretion.

\section{Discussion}

Previous reports have used $\operatorname{cag} A$ status to divide $H$ pylori strains into two main categories: CagA-producing strains which possess the cagA gene, and non-producers which lack the gene. However, a small number of strains possess the gene but do not produce the protein. ${ }^{31}$ This study investigated Japanese isolates belonging to the third category, but not only $\operatorname{cag} A$ was examined but also whole cag PAI.
Japanese strains with the cag PAI partially deleted were further characterised by the absence of all the genes of the cagI region except for $\operatorname{cag} A$ itself and most of the genes in the cagII region. Whereas genes cag6 and cag7, located at the most upstream portion of the cagII, were retained in all of them, cag10, about $4 \mathrm{~kb}$ downstream of $c a g 7$, was deleted in one of four, and cag15, about $6 \mathrm{~kb}$ further downstream, was not detected in any. $\operatorname{cag} B$, located next to cag $A$ in the downstream portion of cagI, and all the genes in the cag PAI from cag 15 to $\operatorname{cag} B$ were deleted. Thus the nucleotide deletion in Japanese cag PAI deleted strains covers most but not all of the cag PAI, with a slight variation in the upstream border. Censini et $a l^{11}$ reported that about $5-10 \%$ of strains had a partial deletion in the cag PAI. The prevalence of cag PAI deleted strains in Japan is the same as in Western countries, but it is not known whether the Western strains had a similar deletion to the Japanese strains.

Most Japanese CagA-non-producing strains lacked cag $A$ transcripts in spite of the presence of the cag $A$ gene, indicating that CagA expression was inhibited at the transcriptional level in these strains. This may be related to the deletion of the $\operatorname{cag} A$ promoter region, which is located between $\operatorname{cag} B$ and $\operatorname{cag} A$. We determined the sequences of the exact downstream border of the deletion in one strain and found that the promoter and the head of the $\operatorname{cag} A$ gene were deleted.

All strains with cag PAI partially deleted were derived from patients with non-ulcer dyspepsia (4/4), whereas only $18 / 59$ strains with cag PAI intact were from such patients and the balance from patients with peptic ulcers or gastric cancer $(p<0.05$; Fisher's exact probability test). Thus the presence of intact cag PAI appears to be a necessary condition for advanced gastroduodenal disease, and this is consistent with the in vitro finding that stimulation of IL-8 secretion from $\mathrm{MKN}-28$ cells was significantly lower with cag PAI deleted strains than with intact ones. Indeed, previous studies using mutagenesis analysis have shown that many genes in the cagI and cagII regions, but not cag $A$ itself, are essential for the induction of IL-8 secretion from epithelial cells. ${ }^{202123}$

According to previous reports, the cag $A$ gene appears to be of use as a marker of whole cag PAI genes and PAI related virulence. ${ }^{21}$ However, this study shows that the presence of the cagA gene does not necessarily indicate the presence of intact cag PAI in Japanese $H$ pylori isolates. It remains to be investigated whether CagA-non-producing strains of this type are found outside of Japan.

Recent studies on the cagA gene in Japan, Korea, and China, where the incidence of gastric cancer is high, have shown that the prevalence of $\operatorname{cag} A$ positive strains is very high with no relation to gastroduodenal disease ${ }^{32-34}$ For example, Pan $e t a l^{\beta 2}$ reported that 47 of 48 strains and 35 of 35 strains from Chinese patients with peptic ulcers and gastritis respectively were positive for the $\operatorname{cag} A$ gene. Infection with cag $A$ positive strains is very common. 
However, our results indicate that genes of the PAI other than $\operatorname{cag} A$ should be also evaluated.

This study reveals another characteristic of Japanese $H$ pylori strains. IS605 is located between cagI and cagII in the prototype $H$ pylori, and reported to be closely associated with the presence of cag PAI. ${ }^{21}$ However, IS605 status in Japanese isolates was not related to cag PAI status: IS605 was detected in 18 of 59 (31\%) strains with cag PAI intact and in two of four $(50 \%)$ with cag PAI partially deleted.

In conclusion, this study shows genetic diversity between Western and Japanese $H$ pylori strains. The non-virulent Japanese strains that do not produce CagA nevertheless retain $\operatorname{cag} A$ and a few other genes in the cag PAI. However, they do not induce IL-8 secretion from MKN-28 cells. Thus the presence of the $\operatorname{cag} A$ gene does not necessarily indicate the presence of intact cag PAI, and cannot be used invariably as a marker of cag PAI related virulence in Japanese strains.

We thank Professor Douglas E Berg for providing the information about cag pathogenicity island and his valuable suggestions. We also thank Dr John Atherton for his gift of cag $A$ negative strains.

1 Warren JR, Marshall BJ. Unidentified curved bacilli on gastric epithelium in active chronic gastritis. Lancet 1983;1:1273-5.

2 NIH consensus conference. Helicobacter pylori in peptic ulcer disease. NIH consensus development panel on
Helicobacter pylori in peptic ulcer disease. $\mathscr{F} A M A$
$1994 ; 272$ Helicobar 9 .

3 Graham DY, Lew GM, Klein PD, et al. Effect of treatment of Helicobacter pylori infection on the long-term recurrence of gastric or duodenal ulcer: a randomized, controlled of gastric or duodenal ulcer: a rand

4 Parsonnet J, Friedman GD, Vandersteen DP, et al. Helicobacter pylori infection and the risk of gastric carcinoma. N Engl f Med 1991;325:1127-31.

5 Nomura A, Stemmermann GN, Chyou PH, et al. Helicobacter pylori infection and gastric carcinoma among
Japanese Americans in Hawaii. N Engl f Med 1991;325: 1132-6.

6 Forman D, Newell DG, Fullerton F, et al. Association between infection with Helicobacter pylori and risk of gastric cancer: evidence from a prospective investigation. $B M f$ 1991;302:1302-5.

7 Covacci A, Censini S, Bugnoli M, et al. Molecular characterization of the $128-\mathrm{kDa}$ immunodominant antigen of Helicobacter pylori associated with cytotoxicity and

8 Tummuru MKR, Cover TL, Blaser MJ. Cloning and expression of a high-molecular-mass major antigen of Helicobacter pylori: evidence of linkage to cytotoxin producHelicobacter pylori: evidence of linkage to
tion. Infect Immun 1993;61:1799-809.

9 Crabtree JE, Taylor JD, Wyatt JI, et al. Mucosal IgA recognition of Helicobacter pylori $120 \mathrm{kDa}$ protein, peptic ulceration, and gastric pathology. Lancet 1991;338:332-5.

10 Ching, CK, Wong, BCY, Kwok, E, et al. Prevalence of CagA-bearing Helicobacter pylori strains detected by the anti-CagA assay in patients with peptic ulcer disease and in controls. Am $\mathcal{F}$ Gastroenterol 1996;91:949-53.

11 Cover TL, Glupczynski Y, Lage AP, et al. Serologic detection of infection with cagA+Helicobacter pylori strains. f Clin Microbiol 1995;33:1496-500.

12 Weel JF, van der Hulst RW, Gerrits Y, et al. The interrelationship between cytotoxin-associated gene A, vacuolating cytotoxin, and Helicobacter pylori-related diseases. F Infect Dis 1996;173:1171-5.
13 Kuipers EJ, Perez-Perez GI, Meuwissen SGM, et al. Helicobacter pylori and atrophic gastritis: importance of the cag $A$ bacter pylori and atrophic gastritis: importan
status. $\mathcal{F}$ Natl Cancer Inst 1995;87:1777-80.

14 Blaser MJ, Perez-Perez GI, Cover TL, et al. Infection with Helicobacter pylori strains possessing cag $A$ Is associated with an increased risk of developing adenocarcinoma of stomach. Cancer Res 1995;55:2111-15.

15 Xiang Z, Bugnoli M, Ponzetto A, et al. Detection in an enzyme immunoassay of an immune response to a recombinant fragment of the 128 kilodalton protein (CagA) of Helicobacter pylori. Eur 7 Clin Microbiol Infect Dis 1993;12: 739-45.

16 Parsonnet J, Friedman GD, Orentreich N, et al. Risk for gastric cancer in people with CagA positive or CagA negative Helicobacter pylori infection. Gut 1997;40:297-301.

17 Crabtree JE, Farmery SM, Lindley IKD, et al. CagA/ cytotoxic strains of Helicobacter pylori and interleukin-8 in gastric epithelial cell lines. F Clin Pathol 1994;47:945-50.

18 Crabtree JE, Covacci A, Farmery SM, et al. Helicobacter pylori induced interleukin-8 expression in gastric epithelial cells is associated with CagA positive phenotype. 7 Clin Pathol 1995; 48:41-5.

19 Sharma SA, Tummuru MK, Miller GG, et al. Interleukin-8 response of gastric epithelial cell lines to Helicobacter pylori stimulation in vitro. Infect Immun 1994;63:1681-7.

20 Akopyants NS, Clifton SW, Kersulyte D, et al. Analysis of the cag pathogenicity island of Helicobacter pylori. Mol Microbiol 1998;28:37-53.

21 Censini S, Lange C, Xiang Z, et al. cag, a pathogenicity island of Helicobacter pylori, encodes type I-specific and disease-associated virulence factors. Proc Natl Acad Sci USA 1996;93:14648-53.

22 Tummuru MKR, Sharma SA, Blaser MJ. Helicobacter pylori picB, a homologue of the Bordetella pertussis toxin secretion protein, is required for induction of IL-8 in gastric epithelial cells. Mol Microbiol 1995;18:867-76.

23 Crabtree JE, Kersulyte D, Hernandez V, et al. Helicobacter pylori induction of IL-8 synthesis in gastric epitherial cells depends on genes throughout the cag pathogenicity islands. [Abstract] Gastroentelorogy 1997;A95.

24 Tomb JF, White O, Kerlavage AR, et al. The complete genome sequence of the gastric pathogen Helicobacter pylori. Nature 1997;388:539-47.

25 Maeda S, Kanai F, Ogura K, et al. High seropositivity of anti-CagA antibody in Helicobacter pylori infected patients irrelevant to the presence of peptic ulcers and gastric cancer in Japan. Dig. Dis Sci 1997;42:1841-7.

26 Maeda S, Ogura K, Yoshida $\mathrm{H}$, et al. Major virulence factors, VacA and CagA, are commonly positive in factors, VacA and CagA, are commonly positive in
Helicobacter pylori isolates in Japan. Gut 1998;42:338-43.

27 Laemmli UK. Cleavage of structural proteins during the assembly of the head of bacteriophage T4. Nature 1970;227:680

28 Sanger F, Nicklen S, Coulson AR. DNA sequencing with chain-terminating inhibitors. Proc Natl Acad Sci USA 1977;74:5463-7.

29 Sambrook J, Fritsch EF, Maniatis T (eds). Molecular cloning: a laboratory manual. Cold Spring Harbor, NY: Cold Spring Harbor Laboratory Press, 1989.

30 Solcov BP, Prockop DJ. A rapid and simple PCR-based method for isolation of cDNAs from differentially expressed genes. Nucleic Acid Res 1994;22:4009-15.

31 Xiang Z, Censini S, Bayeli PF, et al. Analysis of expression of $\mathrm{CagA}$ and VacA virulence factors in 43 strains of Helicobacter pylori reveals that clinical isolates can be divided into two major types and that CagA is not necessary for expression of the vacuolating cytotoxin. Infect Immun 1995;63:94-8.

32 Pan ZJ, van der Hulst RWM, Feller M, et al. Equally high prevalences of infection with cagA-positive Helicobacter pylori in Chinese patients with peptic ulcer disease and pylori in Chinese patients with peptic ulcer disease and
those with chronic gastritis-associated dyspepsia. $\mathcal{F}$ Clin those with chronic gastritis-

33 Miehlke S, Kibler K, Kim JG, et al. Allelic variation in the cagA gene of Helicobacter pylori obtained from Korea compared to the United States. Am f Gastroenterol 1996;91: 1322-5.

34 Shimoyama T, Fukuda S, Tanaka M, et al. High prevalence of the CagA-positive Helicobacter pylori strains in Japanese asymptomatic patients and gastric cancer patients. Scand $\mathcal{F}$ Gastroenterol 1997;32:465-8. 